\title{
Comunnication
}

[Comunicação]

\section{Standardized method to obtain dermo-epidermal junction samples from bovine hoof}

\author{
[Método padronizado para obtenção de amostras da junção derme-epiderme \\ do casco de bovinos] \\ H.M.F. Mendes ${ }^{1}$ and R.R. Faleiros ${ }^{2^{*}}$ \\ ${ }^{1}$ Aluna de pós-graduação - Escola de Veterinária - UFMG - Belo Horizonte, MG \\ ${ }^{2}$ Escola de Veterinária - UFMG - Belo Horizonte, MG
}

Bovine hoof diseases have a highly negative impact on cattle breeding (Warnick, 2001; Ferreira et al., 2003). Injuries such as laminitis, digital dermatitis and interdigital dermatitis are among the most frequent in dairy cattle herds in Brazil as well as in other countries (Silva et al., 2001; Warnick et al., 2001). There are several studies on the prevalence of hoof diseases in dairy cattle (Molina et al., 1999; Mauchle et al., 2008; Silva et al., 2001), which allow the knowledge of epidemiological aspects of such diseases. On the other hand, there is paucity of histological and molecular biology studies of bovine hooves, which may contribute to better understanding of the pathophysiology of laminitis (Thoefner et al., 2005) and infectious diseases (Castro et al., 2008, Osorio et al., 2012). Few studies on histological changes in laminitis and other conditions were performed (Nilsson, 1963; Thoefner et al., 2005; Mills et al., 2009). However, these works have not clearly described a method to obtain standardized samples of the dermo-epidermal junction of the hoof. The absence of this piece of information became the initial obstacle to start new studies. The purpose of this study was to describe an effective method to collect standardized bovine solear and laminar samples for histopathological studies.

Adult cattle slaughtered in a regulated establishment were used in the study, according to the experimental protocol approved by the Ethics Committee on Animal Use
(CETEA/UFMG, protocol number 033/2009). Immediately after slaughtering, feet were obtained through carpo-metacarpal disarticulation. In order to obtain hoof samples, each anatomical part was held by a manual press (4.5"), applied transversely on proximal phalanges, in order to stabilize the nails. As a continuous act, a saw frame and a regular manual saw were used to perform transverse sections in the nails. Those sections were performed from the dorsal region of toe claw, in its middle portions (between the coronary band and the distal end) perpendicularly to the hoof wall and parallel to the sole. Two parallel sections were performed with a distance of 1.5 to $2 \mathrm{~cm}$ between them in order to obtain fragments in the form of slices (Figure 1A), which included part of the distal phalange surrounded by the epidermis and dermis of solear, axial laminar and dorsal laminar regions.

Immediately after collection, these fragments were fixed in $4 \%$ buffered formalin for 48 hours and preserved in $70 \%$ ethanol until manipulation to collect dermo-epidermal junction samples. Initially, the excess of stratum corneum of the sole and wall was trimmed with 13 inches hoof pliers (Figure 1A). The remaining stratum corneum was removed with the use of a disposable high profile blade $(80 \times 14 \mathrm{~mm})$, until it reached the soft tissue, however, aiming to preserve a thin keratinized layer (Figure 1B). 
The solear dermo-epidermal junction sample was the first to be collected. Thus, the blade was introduced on the sole, near the border with the dorsal wall (from outside to inwards), until it reached the distal phalange (Figure 1C). Then, the blade was placed parallel to the bone portion until it reached the opposite end, next to the axial wall (Figure 1D). The collection of this sample was completed after a new section was performed on the stratum corneum towards the dermal stratum, in the opposite side of the initial section (Figure 1E). Similar procedures were performed in order to collect laminar samples of the axial and dorsal regions. The macroscopic aspect of the obtained samples may be seen in Figure1F.

With the purpose of verifying their quality, samples preserved in alcohol were routinely processed, embedded in paraffin and $5 \mu \mathrm{m}$ histological sections were performed. Hematoxylin \& Eosin (H\&E) and Periodic-acid Schiff (PAS) staining techniques, followed by the examination in the light microscope, were employed to verify the histological quality of the sample and the method.

Sample examinations showed that the proposed technique resulted in full-thickness fragments of dermo-epidermal junction, in their solear and laminar regions (axial and dorsal), without fragmentation, distortions and significant presence of artifacts. Also, high quality histological sections could be obtained using $\mathrm{H} \& \mathrm{E}$ and PAS staining techniques, which allowed a wide evaluation of the structures both of the dermis and of the epidermis (Figures IG and $\mathrm{IH}$ ).
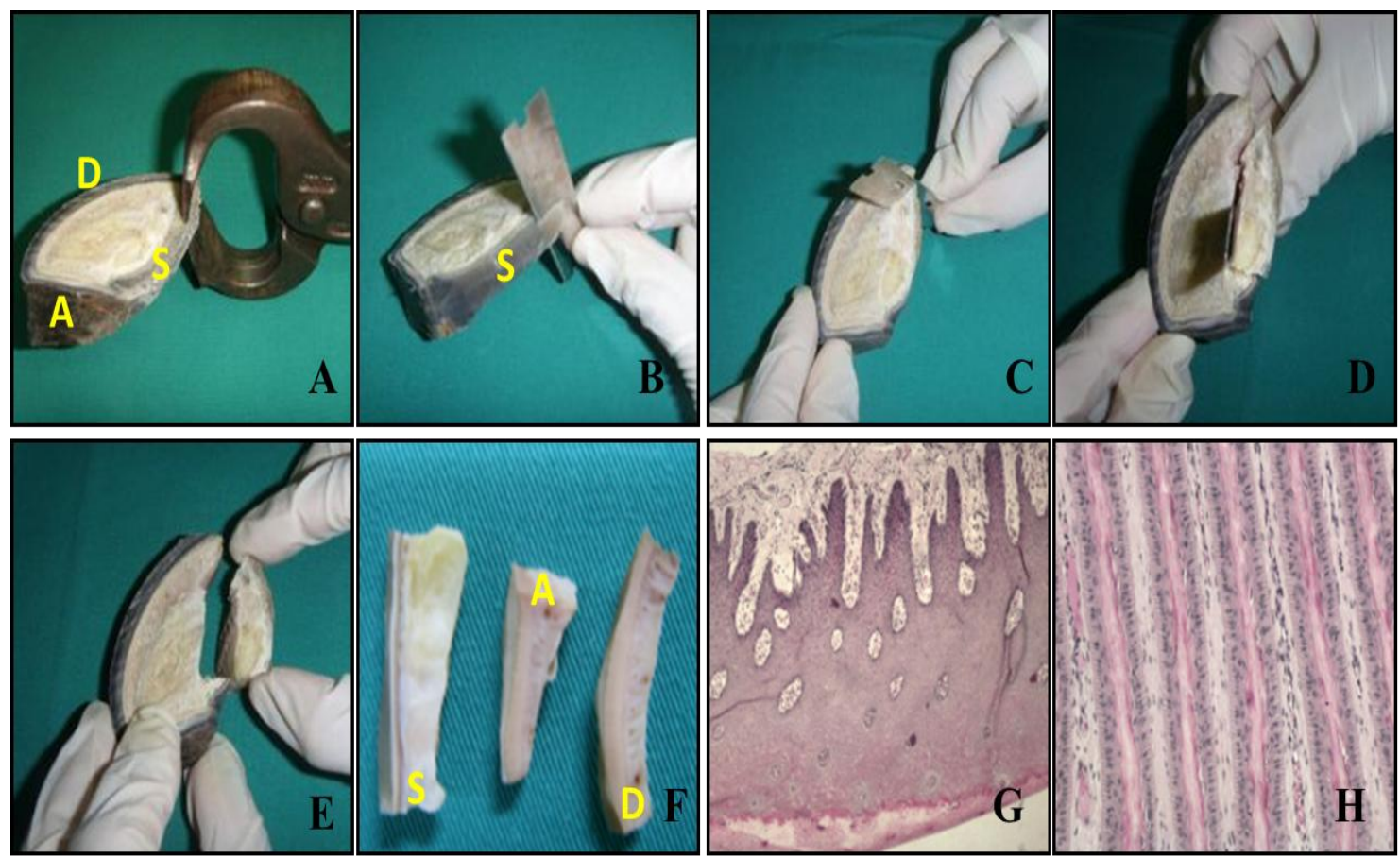

Figure 1. Process for obtaining solear and laminar samples of dermo-epidermal junction. A- Hoof fragment in the form of slices; removal of the excess of stratum corneum with 13 inches hoof pliers; S, A, $\mathrm{D}$ indicate solear, axial and dorsal region; B- trimming of the remaining stratum corneum with a disposable blade; $\mathrm{S}$ indicate solear region; $\mathrm{C}$ - blade insertion from the epidermis towards the dermis perpendicularly to the dermis until it reaches the distal phalange; D- blade being placed parallel to the bone (distal phalange); E- collection of fragment of dermo-epidermal junction from the sole; F- samples of dermo-epidermal junction from solear (S), axial (A) and dorsal (D) regions of the hoof, respectively; G and $\mathrm{H}$ - histological sections (H\&E staining) of the dermo-epidermal junction of solear and dorsal laminar regions, respectively with $4 \mathrm{X}$ and $10 \mathrm{X}$ magnification. 
During the trimming of the stratum corneum with pliers, it was important to evaluate its thickness, which varies among animals. When the thickness of this layer was very thin, the use of pliers was unnecessary, thus the collection of this tissue may be performed directly with a disposable blade. Based on our experience, when the cornified layer was very thin, the use of pliers may damaged the soft tissue and cause changes on it. Hoof pliers seem to be the best tool to collect a large amount of keratinizated tissue. In cases of a thinner trimming of the keratinized layer, only a high profile blade may be used. During the collection of the stratum corneum, it was important to preserve a thin layer of keratinized tissue, in order to maintain histological references during histopathology. Blades should be handled with extra care, in order to avoid accidents.

The technique described in this manuscript was developed to collect dermo-epidermal junction samples from slaughtered or euthanized animals. It is also relevant to highlight that the biopsy of the laminar tissue is another possibility, and it was used in the study of Osorio et al. (2012). However, experimental circumstances do not usually favor the use of biopsy. In accordingly, most studies carried out about histological changes in laminitis were based on samples of animals which were slaughtered or euthanized (Nilsson, 1963; Thoefner et al., 2005, Mills et al., 2009). Unfortunately, these studies did not clarify how to obtain the hoof samples.

Thus, the present communication can be useful providing an easy and step-by-step simple technique to obtain good quality samples of the dermo-epidermal junction, which can be used for histological and molecular biology new studies of the bovine hoof. Also, if adopted by others, this standardized method may facilitate the exchange of samples and results among different research groups.

In conclusion, the proposed method was considered simple, easy to perform, and efficient to obtain standardized samples of the dermoepidermal junction of bovine hoof from euthanized animals producing high quality tissue sections for histological studies.

Keywords: cattle, claw, laminar tissue, dermoepidermal junction, podiatry

\section{RESUMO}

As afecções podais em bovinos causam importante impacto econômico negativo na bovinocultura. Pesquisas têm sido realizadas com o objetivo de avançar no entendimento dos processos ocorridos na junção derme-epiderme do casco de bovinos com laminite e nos demais tecidos moles durante as lesões infecciosas. Apesar disso, não foram encontrados na literatura consultada estudos que descrevessem um método padronizado para a obtenção de amostras do tecido laminar do casco. Nesse contexto, foi necessário criar e estabelecer um método viável para a colheita de amostras da junção derme-epiderme, de modo a viabilizar o estudo de pós-graduação que originou esta comunicação. O objetivo é relatar um método padronizado, testado e bem-sucedido para obtenção de amostras da junção derme-epiderme do casco de bovinos em suas regiões solear, axial e dorsal. Foram obtidos fragmentos transversais das unhas de vacas abatidas em frigorífico. A espessura desses fragmentos foi de 1,5cm, aproximadamente, $e$ contemplava as regiões solear, axial e dorsal do casco. De forma sistematizada, amostras da junção derme-epiderme de cada uma dessas regiões foram removidas, fixadas em formol, processadas $e$ incluídas em parafina. A análise usando microscopia de luz demonstrou cortes histológicos íntegros e sem artefatos, que permitiram ampla avaliação das estruturas tanto da derme quanto da epiderme. Concluiu-se que o método proposto viabiliza a obtenção de amostras de padrão e qualidade adequados ao estudo do tecido laminar do casco bovino.

Palavras-chave: bovino, casco, tecido laminar, junção derme-epiderme, podologia 


\section{ACKNOWLEDGMENTS}

To FAPEMIG and to $\mathrm{CNPq}$ for the financial support.

\section{REFERENCES}

CASTRO, G.R.; BRITO, L.A.B.; FIORAVANTI, M.C.S. et al. Estudo anatomopatológico de lesões de dermatite digital em bovinos. Cienc. Anim. Bras., v.9, p.1159-1166, 2008.

FERREIRA, P.M.; LEITE, R.C.; CARVALHO, A.U. et al. Custo e resultados do tratamento de sequelas de laminite bovina: relato de 112 casos em vacas em lactação no sistema free-stall. Arq. Bras. Med. Vet. Zootec., v.56, p.589-594, 2004.

MAUCHLE, U.; CARVALHO, A.U.; ALZAMORA FILHO, F. et al. Efeito da sazonalidade sobre a ocorrência de lesões podais em vacas leiteiras. Rev. Bras. Saúde e Prod. Anim., v.9, p.109-116, 2008.

MILLS, J.A.; ZARLENGA, D.S.; HABECKER, P.L.; DYERS, R.M. Age, segment, and horn disease affect expression of cytokines, growth factors, and receptors in the epidermis and dermis of the bovine claw. J. Dairy Sci., v.92, p.5977-5987, 2009.
MOLINA, L.R.; CARVALHO, A.U., FACURY

FILHO, E.J. et al. Prevalência e classificação das afecções podais em vacas lactantes na bacia leiteira de Belo Horizonte. Arq. Bras. Med. Vet. Zootec., v.51, p.149-152, 1999.

NILSSON, S.A. Clinical, morphological, and experimental studies of laminitis in cattle. Acta Vet. Scandinavica, v.4, Suppl. 1, 1963. 304p.

OSORIO, J.S.; FRASER, B.C.; GRAUGNARD, D.D. et al. Corium tissue expression of genes associated with inflammation oxidative stress, and keratin formation in relation to lameness in dairy cows. J. Dairy Sci., v.95, p.6388-6396, 2012.

SILVA, L.A.F.; SILVA, L.M.; ROMANI, A.F. et al. Características clínicas e epidemiológicos das enfermidades podais em vacas lactantes do município de Orizona - GO. Cienc. Anim. Bras., v.2, p.119-126, 2001.

THOEFNER, M.B.; WATTLE, O.; POLLITT, C.C. et al. Histopathology of oligofructoseinduced acute laminitis in heifers. J. Dairy Sci., v.88, p.2774-2782, 2005.

WARNICK, L.D.; JANSSEN, D.; GUARD, C.L.; GRÖHN, Y.T. The effect of lameness on milk production in dairy cows. J. Dairy Sci., v.84, p.1988-1997, 2001. 